\title{
Hubungan Kadar Timbal Darah Dengan Jumlah Eritrosit Pada lbu Menyusui
}

\author{
Dewi Sulistyoningrum ${ }^{1}$, Puja Intan Sartika² \\ 1,2Program Studi Administrasi Kesehatan, Sekolah Tinggi IImu Kesehatan Brebes
}

\section{A B S T R A C T}

Human health can be affected by heavy metals in the form of lead which have toxic properties and can accumulate in the body. One of the effects of lead exposure is affecting the hematological system by interfering with heme synthesis, and can shorten the life of red blood cells (erythrocytes) which can cause anemia. The purpose of this study was to determine the relationship between blood lead levels and the number of erythrocytes in breastfeeding mothers. This research is an analytic study with a cross sectional design. The population of all breastfeeding mothers who live in the working area of the Bandarhajro Public Health Center Semarang. The number of samples of 30 respondents were taken by purposive sampling technique. Statistical analysis was performed using the Statistical Package For The Social Sciences (SPSS) version 20. The results of this descriptive study showed that the blood lead level of breastfeeding mothers was on average $62.24 \pm 26.21 \mathrm{~g} / \mathrm{dL}$ with a minimum value of $18.39 \mathrm{~g} / \mathrm{dL}$ and a maximum value of $98.00 \mathrm{~g} / \mathrm{dL}$. The results of bivariate analysis showed that there was no significant relationship between blood lead levels and the number of erythrocytes ( $p=0.195)$. All respondents living in the Bandarharjo Semarang area had blood $\mathrm{Pb}$ levels exceeding the threshold with an average value of 62.24 $\mathrm{g} / \mathrm{dL}$. There was no relationship between the number of erythrocytes and blood $\mathrm{Pb}$ levels in breastfeeding mothers ( $\mathrm{p}$ value $=0.195)$

Keywords : blood lead level; breastfeeding mothers; erythrocyte

ARTICLE INFO
Article history
Received : 22 December 2021
Revised $:$ 27 January 2022
Accepted : 30 January 2022

DOI:

DOI: 10.31983/micajo.v3i1.8136

\section{CORRESPONDING AUTHOR}

$\begin{array}{lll}\text { Name } & : & \text { Dewi Sulistyoningrum } \\ \text { Email } & : & \text { dewisulistyo17@gmail.com } \\ \text { Telp } & : & 085643173853 \\ \text { Address } & : & \text { Desa Kertabesuki RT 05 } \\ & \text { RW 02 Kec. Wanasari, } \\ & \text { Brebes }\end{array}$

ORIGINAL RESEARCH

\section{Pendahuluan}

Logam Timbal atau disebut juga plumbum $(\mathrm{Pb})$ merupakan zat yang berbahaya bagi manusia karenan dapat menyebabkan keracunan yang akut ataupun kronis. (Widowati et al., 2008a) Pada tahun 2019 kematian karena paparan timbal yaitu sebesar 900.000 kematian dan beban tertinggi berada di negera-negera berpenghasilan rendah dan menengah, hal ini dinyatakan oleh Institute for Health Metrics and Evaluation (IHME). (World Health Organization, 2021a)

Di Indonesia, paparan pencemaran timbal sangat membahayakan bagi manusia. Efek samping negatif yang terjadi pada kesehatan manusia yaitu terhadap kesehatan manusia terutama terhadap sistem haemapoitik, saraf, ginjal, gastrointestinal, kardiovaskuler, endokrin, reproduksi dan pencetus karsinogenik. (Rompas, 2015)

Darah mengalirkan Oksigen ke seluruh tubuh, dan sebagai mekanisme pertahanan tubuh terhadap infeksi serta mekanisme hemostatis. (Bakta, 2014). Timbal dalam tubuh manusia akan memengaruhi sistem hematologi dengan cara mengganggu sintesis heme dengan berbagai mekanisme, salah satunya dengan menggangggu melalui gangguan pada aktivasi enzim $\delta$-aminolevulinic acid dehidratase $(\delta-A L A D)$ dan ferrochelatase. Selain hal tersebut, peningkatan kadar timbal dalam darah akan menggagnggu eritropoesis. Hal ini dengan menghambat sintesis protoporfirin sehingga dapat menyebabkan risiko anemia. 
Selain itu, timbal memengaruhi morfologi dan kemampuan hidup sel daraha merah sehingga menyebabkan destruksi pada eritrosit, memperpendek usia eritrosit yang disebut anemia hemolitik. (California Department of Public Health, 2009)

Masuknya timbal pada manusia melalui jalur makana, minuman, udara dan penetrasi pada selaput atau lapisan kulit bagian luar. (Palar, 2017a) Timbal masuk ke lingkungan dan tubuh manusia dari berbgai sumber seperti bensin, makanan, daur ulang ataupun pembuangan baterai mobil, mainan, cat, pipa tanah, kosmetik, pestiida, obat tradisional dan lain-lain. (World Health Organization, 2021)

Dataran rendah seperti pesisir pantai yang berada di wilayah Bandarhajo Semarang merupakan kawasan industri dan jalur transportasi utama dari arah Jawa Tengah menuju Jawa Timur. Pencemaran udara di dapatinya dari asap kendaraan yang mengandung timbal dan penemaran logam berat timbal kemungkinan disebabkan oleh belum optimalnya pengolahan limbah industri di lingkungan sekitar pemukiman.

Efek yang ditimbulkan oleh keracunan timbal pada tubuh manusia dari berbagai kalangan usia, namun risiko tertinggi ada pada ibu hamil, ibu menyusui, anak-anak dan pekerja di industri tertentu yang menggunakan bahan baku dari timbal. Paparan timbal pada tubuh manusia dapat meningkatkan ALA (Aminolevulinic Acid) dalam darah dan urin, meningkatkan kadar protoporphirin dalam sel darah merah, memperpendek umur sel darah merah (eritrosit), menurunkan jumlah sel darah merah, menurunakn kadar retikulosit (sel-sel darah merah yang masih muda) dan meningkatkan kandungan logam Fe dalam plasma darah.(Widowati et al., 2008b) Hal ini akan menghambat sintesis haeme oleh timbal, kemudian eritrosit jumlahnya berkurang sehingga menyebabkan anemia. (Gibney et al., 2009) Jumlah eritrosit yang berkurang mengganggu proses hemopoetik dan akan terjadi penurunan kadar hematokrit dalam sel darah merah serta akan mempengaruhi nilai indeks eritrosit (MCV, $\mathrm{MCH}$ dan $\mathrm{MCHC}$ ).(Arisman, 2011) Belum banyak penelitian yang mengkaji tentang kadar timbal darah pada ibu menyusui di wilayah Bandarharjo Semarang Utara, sehingga peneliti tertarik untuk melakukan penelitian tersebut.

\section{Metode}

Penelitian ini merupakan penelitian analitik dengan rancang cross sectional. Subyek penelitian ini adalah 30 ibu menyusui yang dipilih secara purposif. Data yang dikumpulkan yaitu melalui pemeriksaan sampel darah dilakukan oleh petugas laboratorim, pemeriksaan kadar timbal dalam darah menggunakan metode Atomic Absorbtion Spectrofotometry (AAS), sedangkan pemeriksaan jumlah eritrosit, menggunakan hematology analyzer, pemeriksaan fisik, pengukuran antropometri, wawancara dan observasi. Analisis statistik dilakukan dengan menggunakan Statistical Package For The Social Sciences (SPSS) versi 20. Data penelitian di analisis secara deskriptif pada masing-masing variabel yang diteliti. Analisis dilakukan dengan uji Chi-Square untuk mengetahui hubungan atau ada tidaknya kemaknaan antara variabel bebas dan terikat.

\section{Hasil dan Pembahasan}

1. Analisis Univariat

Berdasarkan hasil penelitian pada 30 ibu menyusui di wilayah Bandarharjo Semarang. Sebagian besar responden berada dalam kategori usia muda sejumlah 26 responden (86,7\%), sedangkan responden dengan kategori usia tua yaitu 4 responden (13,3\%). Berdasarkan Indeks Massa Tubuh (IMT) sebagian besar responden berada dalam kategori normal dan obesitas I masing-masing yakni 9 responden (30\%), kategori 
underweight yaitu 2 responden (6,7\%), overweight yaitu 6 responden (20\%), dan obesitas II yaitu 4 responden (13,3\%).

Tingkat pendidikan sebagian besar berpendidikan SMP sebanyak 12 responden (40,0\%), SD sebanyak 7 responden (23,3\%), SMA sebanyak 10 responden (33,3\%) dan perguruan tinggi hanya 1 responden $(3,3 \%)$. Sementara itu sebagian besar responden tidak bekerja/IRT sebanyak 24 responden $(80,0 \%)$, sebagai buruh tani, pedagang/wiraswasta, pegawai swasta masing-masing 2 responden $(6,7 \%)$.

Tabel 1. Karakteristik Responden

\begin{tabular}{|c|c|c|}
\hline Variabel & $\mathbf{F}$ & $\%$ \\
\hline \multicolumn{3}{|l|}{ Usia } \\
\hline Muda & 26 & 86,7 \\
\hline Tua & 4 & 13,3 \\
\hline \multicolumn{3}{|l|}{ IMT } \\
\hline Underweight & 2 & 6,7 \\
\hline Normal & 9 & 30,0 \\
\hline Overweight & 6 & 20,0 \\
\hline Obesitas I & 9 & 30,0 \\
\hline Obesitas II & 4 & 13,3 \\
\hline \multicolumn{3}{|l|}{ Tingkat Pendidikan } \\
\hline Tidak Tamat SD & 0 & 0,0 \\
\hline SD & 7 & 23,3 \\
\hline SMP & 12 & 40,0 \\
\hline SMA & 10 & 33,3 \\
\hline Perguruan Tinggi & 1 & 3,3 \\
\hline \multicolumn{3}{|l|}{ Jenis Pekerjaan } \\
\hline Tidak Bekerja/IRT & 24 & 80,0 \\
\hline Buruh Tani & 2 & 6,7 \\
\hline Pedagang/Wiraswasta & 2 & 6,7 \\
\hline Pegawai Swasta & 2 & 6,7 \\
\hline
\end{tabular}

Berdasarkan tabel 2 diketahui bahwa rerata kadar $\mathrm{Pb}$ dalam darah yaitu $62,24 \pm 26,21 \mu \mathrm{g} / \mathrm{dL}$ dengan nilai minimum $18,39 \mu \mathrm{g} / \mathrm{dL}$ dan nilai maksimal 98,00 $\mu \mathrm{g} / \mathrm{dL}$. Hasil penelitian menunjukkan bahwa semua responden mempunyai kadar timbal dalam darah melebihi nilai ambang batas yang di tetapkan CDC (2012) yaitu 5,0 $\mu \mathrm{g} / \mathrm{dL}$. Pada hasil pemeriksaan jumlah eritrosit didapatkan rerata yaitu $4,81 \times 10^{6} \mu \mathrm{L}$.

Tabel 2. Hasil Pemeriksaan Laboratorium Kadar Timbal dan Jumlah Eritrosit

\begin{tabular}{lllllll}
\hline Variabel & Mean & Median & SD & Min & Max & NAB/ Kadar Normal \\
\hline Kadar $\mathrm{Pb}$ & 62,24 & 70,35 & 26,21 & 18,39 & 98,00 & $5 \mu \mathrm{g} / \mathrm{dL}$ \\
Eritrosit & 4,81 & 4,73 & 0,84 & 2,53 & 7,60 & $4,2-5,2 \times 10^{6} \mu \mathrm{L}$ \\
\hline
\end{tabular}

Berdasarkan tabel 3, hasil pengkategorian menurut kadar normal untuk variabel jumlah eritrosit, dan nilai cut-off untuk kadar timbal digunakan nilai median 70,35 $\mu \mathrm{g} / \mathrm{dL}$ karena distribusi datanya tidak normal, sehingga diperoleh sebagian besar kadar timbul dalam darah kategori tinggi sebesar $73,3 \%$. Adapun hasil pemeriksaan jumlah eritrosit kategori normal sebanyak $86,7 \%$ dan tidak normal $13,3 \%$. 
Tabel 3. Distribusi Kategori Kadar Pb Dalam Darah Dan Jumlah Eritrosit

\begin{tabular}{lcc}
\hline Variabel $(\mathbf{n}=\mathbf{3 0})$ & $\mathbf{F}$ & $\%$ \\
\hline Kategori Kadar Timbal & & \\
$\quad$ Tinggi $\geq 19,70$ & 22 & 73,3 \\
$\quad$ Rendah $<19,70$ & 8 & 26,7 \\
Kategori Jumlah Eritrosit & & \\
$\quad$ Normal $3,9-5,6 \times 10^{12} / \mathrm{L}$ & 26 & 86.7 \\
$\quad$ Tidak normal $<3,9$ atau $>5,6 \times 10^{12} / \mathrm{L}$ & 4 & 13.3 \\
\hline
\end{tabular}

\section{Analisis Bivariat}

Dibawah ini merupakan analisis bivariat. Tabel 4 menunjukkan hubungan antara eritrosit dengan kadar $\mathrm{Pb}$ darah dapat diketahui bahwa frekuensi responden yang memiliki kadar $\mathrm{Pb}$ darah rendah dengan eritrosit normal $(30,8 \%)$ lebih besar dibandingkan dengan eritrosit tidak normal $(0,0 \%)$. Hasil uji Chi-Square diperoleh nilai $p$-value adalah $0,195>$ 0,05 artinya tidak ada hubungan antara jumlah eritrosit dengan kadar $\mathrm{Pb}$ darah pada ibu menyusui.

Tabel 4. Hasil Analisis Hubungan Kadar Pb Dalam Darah Dengan Jumlah Eritrosit Pada Ibu Menyusui

\begin{tabular}{|c|c|c|c|c|c|c|c|}
\hline \multirow{3}{*}{ Kategori } & \multicolumn{4}{|c|}{ Kadar Pb } & \multirow{2}{*}{\multicolumn{2}{|c|}{ Total }} & \multirow{3}{*}{ P-Value } \\
\hline & \multicolumn{2}{|c|}{ Rendah } & \multicolumn{2}{|c|}{ Tinggi } & & & \\
\hline & $\mathbf{n}$ & $\%$ & $\mathbf{n}$ & $\%$ & $\mathbf{N}$ & $\%$ & \\
\hline Eritrosit Normal & 8 & 30.8 & 18 & 69.2 & 26 & 100 & 0,448 \\
\hline Eritosit Tidak Normal & 2 & 50.0 & 2 & 50.0 & 4 & 100 & \\
\hline
\end{tabular}

Hasil analisis data penelitian ini terlihat bahwa responden yang tinggal di wilayah Bandarharjo Semarang memiliki kadar $\mathrm{Pb}$ darah tinggi sebesar 73,3\%. Peneliti menganalisis ada beberapa faktor yang membuat kadar pb darah tinggi yaitu asupan makanan atau asupan gizi dan lingkungan di sekitar wilayah Bandarharjo Semarang.

Hasil analisis hubungan antara jumlah eritrosit dengan kadar $\mathrm{Pb}$ darah pada ibu menyusui dapat dijelaskan bahwa dari 26 ibu yang memiliki jumlah eritrosit yang normal dengan kadar $\mathrm{Pb}$ darah yang rendah sebanyak 8 orang $(30,8 \%)$ dan yang kadar $\mathrm{Pb}$ darah tinggi sebanyak 18 orang $(69,2 \%)$. Berdasarkan hasil uji hubungan antara jumlah eritrosit dengan kadar $\mathrm{Pb}$ darah pada ibu menyusui menggunakan uji chi-square menunjukkan bahwa tidak ada hubungan yang signifikan antara keduanya. Hal ini dapat disebabkan oleh faktor lain, seperti asupan gizi atau nutrisi dan lingkungan. Berdasarkan observasi di lapangan yang dilakukan oleh peneliti, ditemukan bahwa responden terbiasa mengkonsumsi makanan laut, karena pasarnya dekat dengan dermaga pengelolaan ikan. Di samping itu juga banyak pabrik yang didirikan diwilayah tersebut sehingga dapat kemungkinan air dan makanan laut dapat terkontaminasi dengan limbah pabrik.

Hemoglobin $(\mathrm{Hb})$ merupakan bagian dari sel darah merah atau eritrosit yang berfungsi untuk memberi warna pada eritrosit dan mengikat oksigen di dalam darah. Untuk pembentukan sel darah merah berada di daerah sumsum tulang belakang. Apabila tulang belakang berfungsi baik maka pembentukan sel darah merah dan eritrosit membutuhkan waktu sekitar 5-9 hari, dan umur sel darah merah dan $\mathrm{Hb}$ adalah sekitar 120 hari. (WHO, 2011) 
Timbal yang masuk dalam tubuh dapat mengganggu sistem sintesa $\mathrm{Hb}$ dengan cara menghambat konversi Delta Aminoleculinic Acid (Delta ALA) menjadi porphobilinogen dan menghambat korporasi dari Fe ke dalam protophorpirin IX untuk membentuk $\mathrm{Hb}$. Timbal yang masuk ke paru-paru akan terserap dan berikatan dengan darah paru-paru dan di edarkan ke seluruh jaringan dan organ tubuh. Logam $\mathrm{Pb}$ yang terserap oleh darah 90\% akan berikatan dengan sel darah merah.(Palar, 2017b)

Waktu paruh timbal di dalam darah sekitar 36 hari, pada jaringan lunak sekitar 40 hari dan pada tulang sekitar 25 tahun. Sekresi timbal pada umumnya berjalan lambat, sehingga menyebabkan timbal mudah terakumulasi di dalam tubuh.(Adnan, 2001)

Pembentukan sel darah merah yang cenderung lebih cepat dibandingan dengan timbal yang terakumulasi di dalam tubuh dapat menggantikan eritrosit yang hancur akibat timbal. Jika hal ini didukung dengan mengkonsumsi asupan gizi atau nutrisi yang baik dan tercukupi di dalam tubuh. (Setyoningsih et al., 2016)

\section{Simpulan}

Semua responden yang tinggal di wilayah Bandarharjo Semarang memiliki kadar $\mathrm{Pb}$ darah melebihi ambang batas dengang nilai rata-ratanya adalah 62,24 $\mu \mathrm{g} / \mathrm{dL}$. Tidak ada hubungan antara jumlah eritrosit dengan kadar $\mathrm{Pb}$ darah pada ibu menyusui.

\section{Ucapan Terimakasih}

Terimakasih kami ucapkan kepada seluruh pemangku kepentingan baik instansi, peneliti dan responden yang terlibat dan membantu dalam penelitian ini.

\section{Daftar Pustaka}

Adnan, S. (2001). Pengaruh Pajanan Timbal Terhadap Kesehatan dan Kualitas Semen Pekerja Laki-Laki. Majalah Kedokteran Indonesia, 51 No 5, 168-174.

Arisman, M. (2011). Gizi Dalam Daur Kehidupan. Jakarta: EGC.

Bakta, I. M. (2014). Hematologi Klinik Ringkas. Buku Kedokteran EGC.

California Department of Public Health. (2009). Medical Guidelines for the Lead-Exposed Worker. April 2009.

Gibney, M., Margetts, B., Kearney, J., \& Arab, L. (2009). Gizi Kesehatan Masyarakat. EGC.

Palar, H. (2017). Pencemaran \& Toksikologi Logam Berat. Rineka Cipta.

Rompas, R. M. (2015). Toksikologi Kelautan. Jakarta: Sekretariat Dewan Kelautan Indonesia.

Setyoningsih, O. S., Setiani, O., \& Darundari, Y. H. (2016). Hubungan Antara Paparan Timbal $(\mathrm{Pb})$ dengan Laju Endap Darah pada Pekerja Bagian Pengecatan Industri Karoseri di Semarang. Jurnal Kesehatan Masyarakat (e-Journal), 4(3), 852-861.

WHO. (2011). Haemoglobin concentrations for the diagnosis of anaemia and assessment of severity. Vitamin and Mineral Nutrition Information System. Geneva, World Health Organization., 1-6. https://doi.org/2011

Widowati, W., Sastiono, A., \& R, R. J. (2008). Efek Toksik Logam Pencegahan dan Penanggulangan Pencemaran.

World Health Organization. (2021). Lead Poisoning. 
